\title{
Shallow-water refuge paradigm: conflicting evidence from tethering experiments in a tropical estuary
}

\author{
Ron Baker ${ }^{1,2,3, *}$, Marcus Sheaves ${ }^{1,2}$ \\ ${ }^{1}$ Estuarine and Coastal Ecology Group, School of Marine and Tropical Ecology, James Cook University, Townsville, \\ Queensland 4811, Australia \\ ${ }^{2}$ Cooperative Research Centre for Coastal Zone, Estuary and Waterway Management, Indooroopilly Sciences Centre, \\ 80 Meiers Road, Indooroopilly, Queensland 4068, Australia \\ ${ }^{3}$ Present address: NOAA Fisheries Service, SEFSC Galveston Lab, 4700 Ave U, Galveston, Texas 77551, USA
}

\begin{abstract}
The shallow-water refuge paradigm has been globally applied to help explain the high abundances of juvenile fishes that utilise shallow-water estuarine nursery habitats. Despite the wide application and acceptance of the paradigm, there is little direct evidence to indicate that small juvenile fishes benefit from reduced predation pressure in shallow water habitats relative to adjacent deeper waters. The present study employed chronographic tethering experiments to examine patterns in predation potential across a depth gradient $(0.2$ to $3 \mathrm{~m})$ in the lower reaches of a tropical estuary in northeastern Queensland, Australia. Over 6 mo, 17 replicate experimental trials were conducted, deploying a total of 183 tethered fish prey. Despite the clear and consistent patterns found in the few previous studies elsewhere in the world, there was no significant effect of depth on predation pressure, and thus no evidence of lower predation pressure in the shallow relative to the adjacent deeper estuarine waters examined in the present study. The findings suggest that the shallow-water refuge paradigm may be too simplistic for diverse and complex tropical estuarine nursery grounds.
\end{abstract}

KEY WORDS: Nursery · Tropical estuary $\cdot$ Predation $\cdot$ Refuge paradigm

\section{INTRODUCTION}

Shallow-water estuarine habitats around the globe are dominated by small and juvenile fishes and crustaceans (Blaber 1980, Kneib 1997, Sheaves 2006). Despite the long-held recognition of the importance of these systems as nurseries for a diverse range of nekton (e.g. Boesch \& Turner 1984), the actual processes driving shallow-water habitat use remain unclear (Craig \& Crowder 2000, Deegan et al. 2000, Sheaves 2001, 2005, Minello et al. 2003, Rountree \& Able 2006). The idea that shallow-water habitats in estuaries provide vulnerable nekton with a refuge from predation is one of the fundamental paradigms of estuarine nursery-ground ecology (e.g. Blaber \& Blaber 1980, Boesch \& Turner 1984, Paterson \& Whitfield 2000). However, there is very little direct evidence that the occupation of shallow waters actually reduces predation-induced mortality relative to adjacent deeper habitats (Craig \& Crowder 2000, Deegan et al. 2000, Sheaves 2001).

The potential refuge value of shallow estuarine nurseries for fishes has usually been inferred indirectly from patterns of habitat use by juveniles and/or piscivores (Blaber \& Blaber 1980, Paterson \& Whitfield 2000). Observations of high densities of small juveniles and apparently low numbers of large, primarily piscivorous fishes in shallow habitats has led to the conclusion that predation pressure is lower in shallow than in adjacent deeper waters and that shallow waters provide refuge (Blaber 1980, Blaber \& Blaber 1980, Paterson \& Whitfield 2000).

When the full spectrum of potential predators is considered, rather than just large primary piscivores, it is apparent that the shallow-water estuarine piscivore assemblage may have been significantly underestimated (Baker \& Sheaves 2005). However, such 
findings do not clarify and certainly do not refute the shallow-water refuge hypothesis. Because of the difficulties of sampling shallow and adjacent deeper habitats in a comparable manner (Kneib 1997, Rozas \& Minello 1997, Rountree \& Able 2006), few studies have been able to directly compare the abundances of juvenile fishes and their predators in shallow and adjacent deeper waters in a meaningful way, making conclusions about the relative abundance of piscivores in shallow waters ambiguous. There is also evidence that the abundance of some large (>100 $\mathrm{mm}$ ) primary piscivores may have been considerably underestimated in shallow waters due to sampling biases (Rountree \& Able 1997, Baker \& Sheaves 2006). Even in cases when the abundance of predators and/or prey can be measured comparably among habitats (e.g. Paterson \& Whitfield 2000), the relative abundance of piscivores in adjacent habitats does not necessarily reflect relative predation pressure because individual predators may not feed equally in all habitats they occupy (Abrams 1993, Haywood \& Pendrey 1996, Sheaves 2001).

The most direct evidence of reduced predation pressure in shallow estuarine waters relative to adjacent deeper waters has come from tethering experiments in a few temperate estuaries in North America (McIvor \& Odum 1988, Ruiz et al. 1993, Clark et al. 2003, Manderson et al. 2004). Higher relative predation rates on small fish and mobile crustaceans tethered in deep water compared with adjacent shallow waters provides support for the shallow-water refuge hypothesis. Although tethering experiments are not without their problems (Peterson \& Black 1994, Kneib \& Scheele 2000), all techniques applied to sampling estuarine fish faunas have their limitations, which must be considered when interpreting results (Boesch \& Turner 1984, Aronson \& Heck 1995, Kneib 1997, Rozas \& Minello 1997).

Perhaps the most serious issue in the interpretation of tethering experiments is the potential for interaction between experimental artefacts and treatments (Peterson \& Black 1994, Kneib \& Scheele 2000, Haywood et al. 2003). Tethering experiments can only measure relative predation pressure, or predation potential (Aronson \& Heck 1995), rather than absolute predation pressure because of the artefact of altered vulnerability of tethered prey relative to non-tethered prey (Curran \& Able 1998, Manderson et al. 2004). The effect of tethering on prey vulnerability is assumed to be constant across all treatments and therefore the measured patterns of predation potential are assumed to reflect patterns in actual predation pressure among treatments, thus providing meaningful interpretations (Aronson \& Heck 1995). However, if the effects of tethering on measured predation pressure interact with treatment, then the measured pattern of predation potential will be confounded and potentially meaningless (Peterson \& Black 1994, Kneib \& Scheele 2000). For example, tethered prey may become vulnerable to predators that normally do not consume non-tethered prey, and the abundance of these predators may vary significantly among treatments, such as may occur when comparing predation potential between vegetated and unvegetated habitats (e.g. Peterson et al. 2001, Haywood et al. 2003). Interactions may also result from differences in the behaviour or escape responses of tethered prey between habitats (treatments) (e.g. Barshaw \& Able 1990, Curran \& Able 1998). For example, the ability of tethered juvenile lobsters to burrow and escape predators differs to that of non-tethered lobsters in some habitats but not others (Barshaw \& Able 1990). In such cases, the measured patterns of predation potential across treatments may bear little resemblance to the actual patterns in predation pressure on untethered prey (Haywood et al. 2003).

Interactions between experimental artefacts and treatments are most likely to be a problem when the composition of the predator assemblage or the physical nature of the habitats differs considerably between treatments (Peterson \& Black 1994). Comparisons of adjacent simple habitats differing only in depth are less likely to cause confounding interactions (Manderson et al. 2004). With due consideration given to, and attempts to overcome the limitations of the technique, tethering experiments provide one of the few direct approaches to quantifying relative predation pressure between habitats within dynamic estuarine ecosystems (Aronson \& Heck 1995, Aronson et al. 2001, Rountree \& Able 2006).

The aim of the present study was to directly determine if the shallow waters inhabited by small fishes in tropical estuaries provide them with a refuge from predation. Tethering experiments were used to examine patterns of predation potential across a depth gradient in a tropical estuary in northeastern Queensland, Australia.

\section{MATERIALS AND METHODS}

Study sites. Depth-related patterns in predation pressure were examined during 17 field experiments. Between 22 August 2003 and 30 January 2004, 16 tethering trials were conducted at Victoria Creek $\left(18^{\circ} 38^{\prime} \mathrm{S}, 146^{\circ} 20^{\prime} \mathrm{E}\right), \sim 100 \mathrm{~km}$ northwest of Townsville, Australia. Thirteen trials were conducted during daylight hours and 3 trials at night. This estuary was chosen because there were numerous suitable sites in its lower reaches, and because it was easily accessible for night-time sampling. An initial trial using 6 chrono- 
graphs was run in Ross River, Townsville, on 24 July 2003; however, chronographs set $>2 \mathrm{~m}$ deep at low tide were by necessity in the middle of the shipping channel, making this an unsuitable site for further experimental trials. The maximum tidal range in this region is $\sim 4 \mathrm{~m}$.

Each experimental site consisted of an area $\sim 200 \mathrm{~m}$ long $\times 100 \mathrm{~m}$ wide, with sandy substrate gently sloping from straight, featureless shoreline into $>2.5 \mathrm{~m}$ of water. Consequently, chronographs set in 2.5 to $3 \mathrm{~m}$ of water were between 50 and $100 \mathrm{~m}$ from the shore. Although some sites were adjacent to mangroves and/or marsh vegetation higher in the intertidal zone, each experimental trial was timed such that the tide was below any vegetation for the duration of the experiment. Therefore each site consisted of unstructured, non-vegetated, essentially homogeneous sandy habitat, varying only in depth along a gradient perpendicular to the shore. These site characteristics were chosen because they allowed, as far as is practically possible, the separation of the effect of depth on predation pressure from all other observable habitat variables, such as the presence of vegetation or woody debris and variations in shoreline structure. Similarly, it was assumed that the effect of tethering on prey vulnerability was constant across the depth range sampled because the treatments differed only in depth, minimising the probability of an interaction between treatment and the vulnerability of tethered prey (Manderson et al. 2004). Sites were chosen where boat traffic was low to minimise disturbance during experimental trials.

Chronograph design. A chronographic tether is a device that allows the measurement of survival time of tethered prey (Minello 1993). The submersible chronographs used in this study were constructed on the same principle as previously described devices (Minello 1993, Haywood \& Pendrey 1996); when a predator removes a prey from the tether line, a switch is triggered, stopping a clock, thus measuring survival time. Fish were tethered on $35 \mathrm{~cm}$ of $2.7 \mathrm{~kg}$ monofilament fishing line ( $0.23 \mathrm{~mm}$ diameter) passed through a small hole pierced through the membrane behind the lower jaw of the fish. This attachment method allowed normal swimming by the tethered fish. Each chronograph was deployed and retrieved by a $3.5 \mathrm{~m}$ length of $30 \mathrm{~kg}$ monofilament fishing line attached to a $15 \mathrm{~cm}$ diameter styrofoam float. The chronograph design ensured that the tethered fish could not reach and tangle in the chronograph or float line.

Field methodology and justification. Within each site, between 9 and 12 chronographs were deployed across the depth range between 0.2 and $3 \mathrm{~m}$. Individual chronographs were set $\geq 20 \mathrm{~m}$ apart to ensure independence of each predation event. It was assumed that, at this spacing, a predator consuming a prey teth- ered to 1 chronograph would not be able to detect the next nearest tethered prey, and therefore each predation event could be considered independent.

The depth range sampled was chosen based on the depth distribution of common small prey fishes from the region. A range of small and juvenile fishes ( $<100 \mathrm{~mm}$ fork length [FL]) that are common prey in the diets of estuarine piscivores in northeastern Australia (Baker \& Sheaves 2005) show both maximum densities and highest probability of encounter in waters $<1 \mathrm{~m}$ deep, with very few individuals encountered in waters $>1.5 \mathrm{~m}$ deep (our Fig. 1; R. Johnston unpubl. data). Thus the depth range sampled (0.1 to $3 \mathrm{~m}$ ) spans from the shallow waters in which small prey fish are most commonly encountered and most abundant, into the adjacent deeper waters from which they are virtually absent. While a number of taxa were tethered throughout the study, only similarly sized individuals of 1 taxon were used in each experimental trial. Prey fish used in each trial were collected with a $6 \mathrm{~mm}$ mesh seine net from the estuary on the day of each experiment. The taxon used was the most abundant common forage fish sampled on each occasion.

Each experimental trial was run for 2 to $3 \mathrm{~h}$. Although longer sets may have provided higher incidences of prey consumption (e.g. Minello 1993, Haywood \& Pendrey 1996), the large tidal range meant that chronographs set in $<0.5 \mathrm{~m}$ of water would either be in water $>0.5 \mathrm{~m}$ or dry on the shore before the end of the trial period. In an effort to ensure representative and controlled sampling of each depth zone, experimental trials were run across the turn of the tides, or during periods of minimal tidal movement. An additional problem with longer soak times is the increased likelihood of predation by non-piscivores able to capture prey fatigued from being tethered for many hours.

Analysis. Time and water depth were recorded at both deployment and retrieval of each chronograph. This was used in conjunction with measured survival time, observed tidal movements, and tide predictions from tide charts to estimate the depth at the time of predation. When no predation event was recorded, the median depth between deployment and retrieval was used in analyses.

Logistic regression was used to test for a significant effect of depth on prey survival. If shallow waters provide the tethered fish with lower predation pressure than the adjacent deeper waters, the data recorded as presence or absence ( $0=$ survival, $1=$ predation event $)$ should show a sigmoidal response providing a significant fit of a logistic regression (Fig. 2). The transition from survival to predation events would indicate a critical depth where predation pressure changes. Given the depth distributions of common small and juvenile fishes in this region (Fig. 1), such a transition would be 

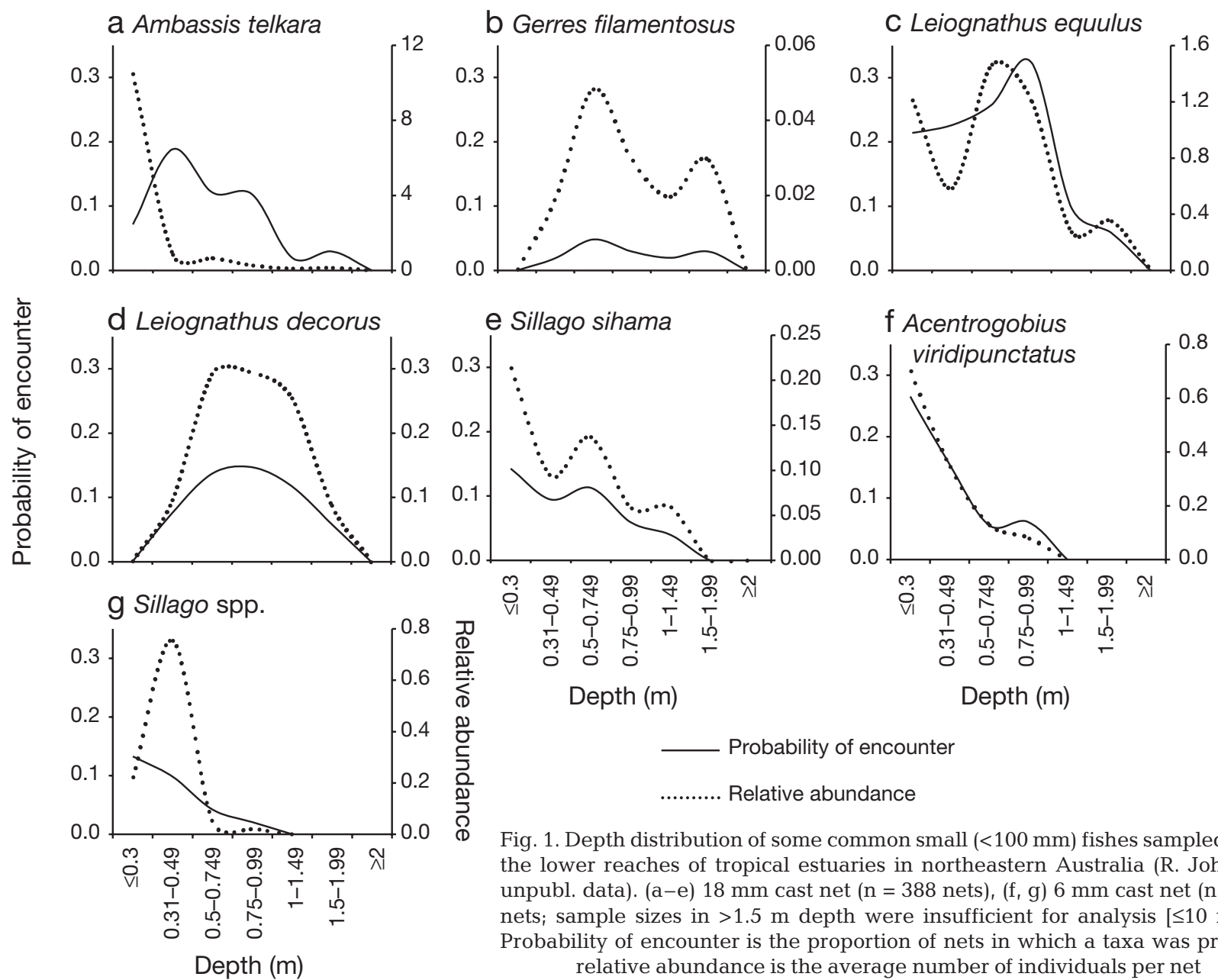

Probability of encounter

Relative abundance

Fig. 1. Depth distribution of some common small $(<100 \mathrm{~mm})$ fishes sampled from the lower reaches of tropical estuaries in northeastern Australia (R. Johnston unpubl. data). (a-e) $18 \mathrm{~mm}$ cast net ( $\mathrm{n}=388$ nets), (f, $\mathrm{g}) 6 \mathrm{~mm}$ cast net $(\mathrm{n}=950$ nets; sample sizes in $>1.5 \mathrm{~m}$ depth were insufficient for analysis [ $\leq 10$ nets]). Probability of encounter is the proportion of nets in which a taxa was present; relative abundance is the average number of individuals per net

expected at between 1 and $2 \mathrm{~m}$ depth. Interaction terms were added to the logistic regression model to test for the effect of depth on predation pressure among subsets of experiments grouped according to tide state (low or high), moon phase (1st quarter, full, or

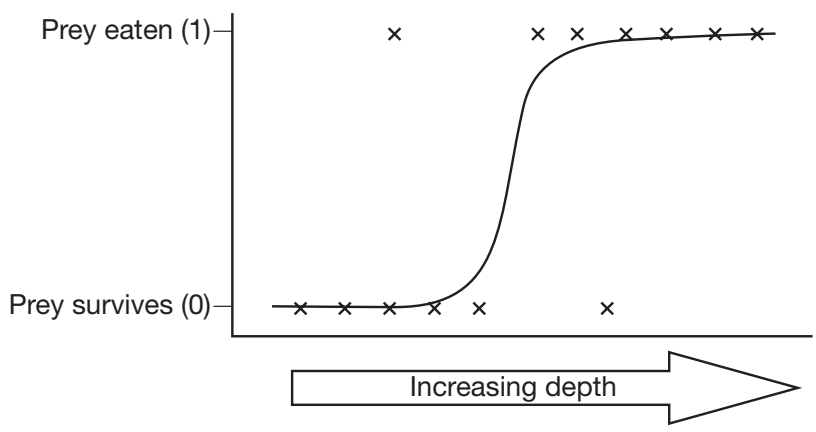

Fig. 2. Hypothetical result of tethering experiments if shallow waters have lower levels of predation on tethered fish prey, and thus provide a refuge from predation. Result would be a sigmoidal response with a significant fit of a logistic regression last quarter), and diurnal period (day or night) (see Fig. 3). Analyses were conducted both pooled across all prey species, and separately for Sillago spp., the most commonly tethered prey taxa. A lack of a significant fit of a logistic regression to the tethering data would indicate that predation pressure is not lower in shallow water than in the adjacent deep water.

\section{RESULTS}

Seventeen trials were run for a total of 183 chronograph sets. Forty-six tethered fish $(25 \%)$ were either missing $(\mathrm{n}=32)$ or showed visible signs of attack by predators $(n=14)$ and these were recorded as predation events (Fig. 3). A maximum of 7 predation events were recorded during a single trial (Fig. 3g), and during 2 trials, no prey were taken or showed signs of attack. In one of the trials in which no prey were taken, all were retrieved dead and this trial was excluded from further analysis. Between 1 and 3 predation events were recorded during the 3 night trials (Fig. 3i,l,o). 
a) $24 \mathrm{Jul} 03$

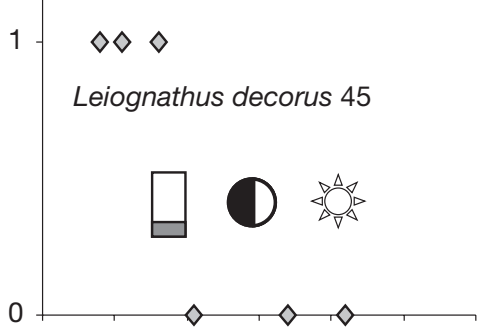

d) $12 \operatorname{Sep} 03 a$

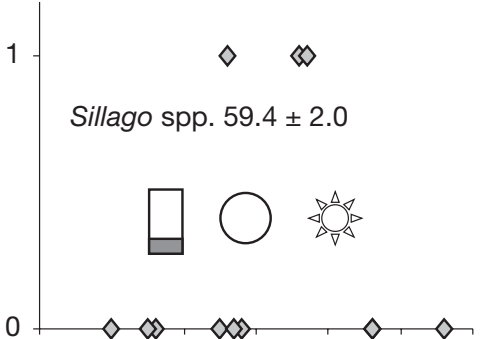

g) $10 \mathrm{Dec} 03 \mathrm{a}$
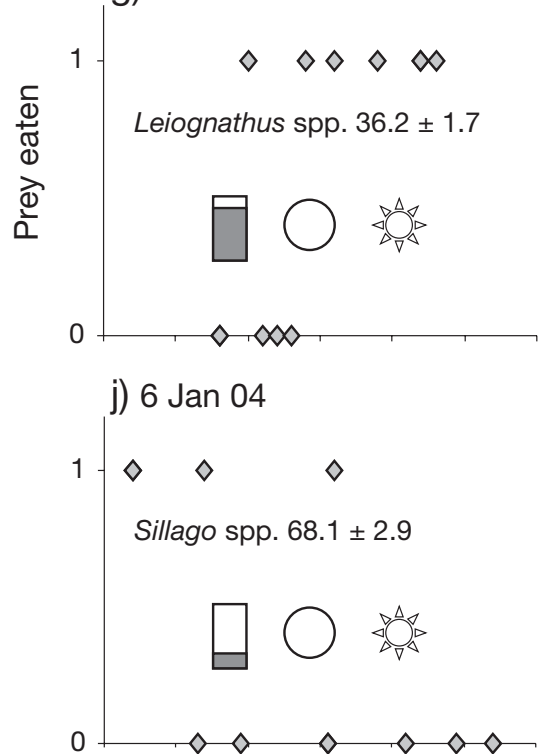

m) 30 Jan 04a

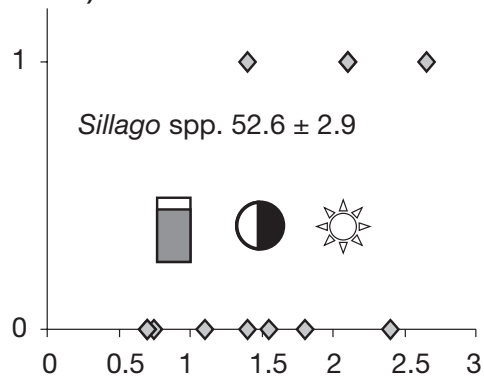

b) 22 Aug 03a

$\diamond$

Ambassis telkara $51.5 \pm 0.5$
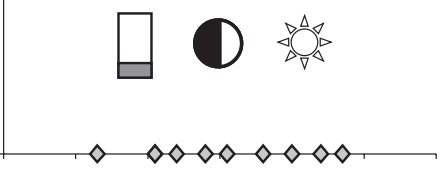

e) 12 Sep 03b

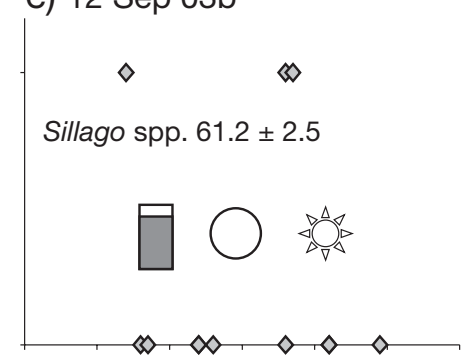

h) $10 \mathrm{Dec} 03 \mathrm{~b}$

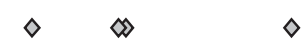

Sillago spp. $65.2 \pm 2.7$

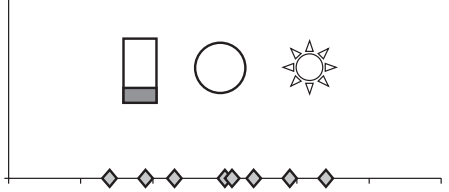

k) 29 Jan $04 a$

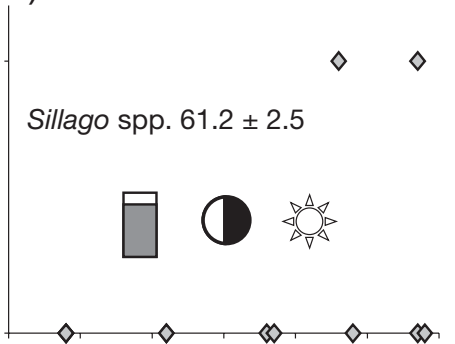

n) 30 Jan $04 \mathrm{~b}$

$\diamond \diamond$

Sillago spp. $71.3 \pm 2.2$

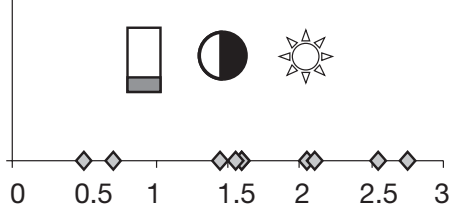

c) 22 Aug 03b

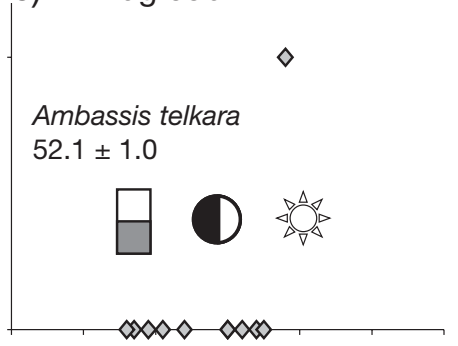

f) 12 Nov $03 a$

$\diamond \diamond \diamond \quad \bowtie$

Gerres filamentosus

$37.9 \pm 0.5$
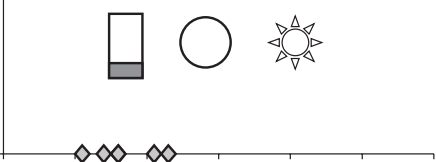

i) 5 Jan 04

$$
\diamond
$$

$\diamond \diamond$

Leiognathus spp.

$48.0 \pm 0.9$

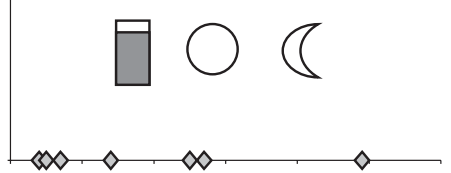

l) 29 Jan $04 \mathrm{~b}$

$\bowtie \quad \diamond$

Sillago spp. $73.8 \pm 1.3$

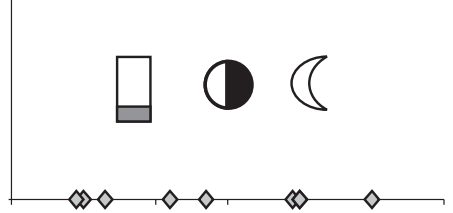

o) 30 Jan $04 d$

$\diamond$

Liza vagiensis $50.8 \pm 1.7$

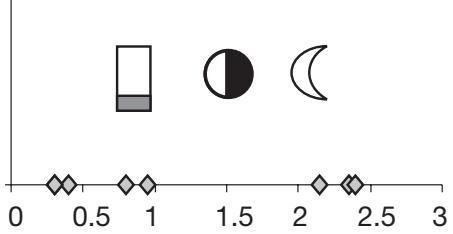

Water depth (m)

Fig. 3. Depth-related patterns in predation pressure on fish tethered across a depth gradient in tropical estuaries of northeastern Australia. 1 = predation event, 0 = prey survived. (a) Ross River, $(\mathrm{b}-\mathrm{o})$ Victoria Creek. Species name given with size (fork length in $\mathrm{mm} \pm 1 \mathrm{SE}$ ) of tethered prey fish. Shaded bar: tide state; circle: moon phase (1st quarter, full, or last quarter); sun/moon: day/night. Not shown are 2 experiments in which no predation events were recorded (12 Nov 03b, 30 Jan 04c) 
Sampling was targeted at times of minimal water movement, and the maximum change in depth recorded between deployment and retrieval was $0.7 \mathrm{~m}$. Despite this and other efforts to ensure representative sampling across the depth range, the shallowest $(<0.5 \mathrm{~m})$ and deepest $(>2.5 \mathrm{~m})$ depth zones were underrepresented. Seventeen replicates were recorded in $<0.5 \mathrm{~m}$ and 10 replicates in $>2.5 \mathrm{~m}$, while each of the $0.5 \mathrm{~m}$ depth zones between 0.5 and $2.5 \mathrm{~m}$ had between 34 and 41 replicate chronograph sets (Fig. 4).

\section{Patterns in predation pressure}

Relative predation pressure was highly variable and no clear depth-related patterns emerged during the trials (Figs. 3 \& 4). Tethered prey were consumed across virtually the entire depth range sampled, with the shallowest and deepest predation events recorded in 0.15 and $2.85 \mathrm{~m}$, respectively (Fig. 3). In 4 trials, predation events were recorded only on individuals tethered in shallow waters $(\leq 1.5 \mathrm{~m})$ (Fig. $3 \mathrm{a}, \mathrm{b}, \mathrm{l}, \mathrm{n})$; in 3 trials, predation pressure was focused on individuals tethered in deeper water (Fig. 3c,k,o). For the remaining trials in which predation events were recorded, prey were taken across the depth range or only at intermediate depths. All terms in the logistic regression models were nonsignificant (Table 1). There was no effect of depth on predation pressure, either within all experiments pooled, or within subsets of experiments grouped according to prey species, tide state, moon phase, or diurnal period (Table 1).

The average proportion of tethered prey consumed per experiment in $<0.5 \mathrm{~m}$ of water $(57 \%)$ was the highest of any depth zone (Fig. 4). However, sample size in

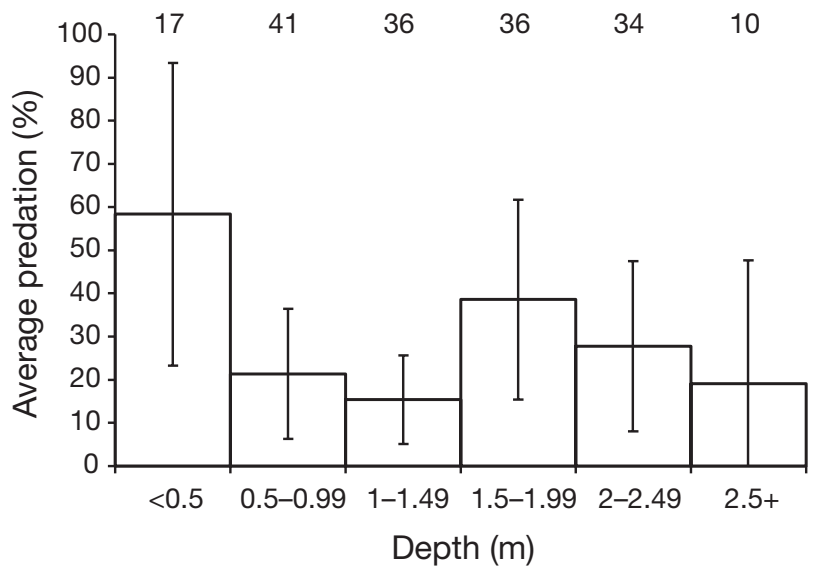

Fig. 4. Profile of predation pressure $( \pm 95 \% \mathrm{CI})$ on tethered fish across a depth gradient along sandy shores in the lower reaches of tropical estuaries, as measured by chronographic tethering experiments ( $\mathrm{n}=16$ experiments). Total number of chronographs set in each depth zone is shown above each bar
Table 1. Logistic regression testing the effect of depth on predation on prey fish tethered across a depth gradient in a tropical estuary in northeastern Queensland, Australia

\begin{tabular}{|lccc|}
\hline Effect & df & Wald test & $\mathrm{p}$ \\
\hline All species & & & \\
$\quad$ Depth & 1 & 0.649240 & 0.420384 \\
Depth $\times$ Day/night & 1 & 0.085548 & 0.769916 \\
Depth $\times$ Tide state & 2 & 2.093190 & 0.351131 \\
Depth $\times$ Moon phase & 2 & 3.090584 & 0.213250 \\
Sillago spp. & & & \\
Depth & 1 & 1.783333 & 0.181741 \\
Depth $\times$ Day/night & 1 & 0.398360 & 0.527937 \\
Depth $\times$ Tide state & 1 & 0.578475 & 0.446911 \\
Depth $\times$ Moon phase & 1 & 0.263902 & 0.607452 \\
\hline
\end{tabular}

this depth zone was low $(\mathrm{n}=17)$, variability in predation pressure at all depths was high (Fig. 4), and the high average reflects a number of experimental trials in which each of the 1 or 2 prey tethered in $<0.5 \mathrm{~m}$ were consumed. The profile of predation pressure was effectively the same whether viewed as the average percentage of tethered prey attacked per depth range per trial (Fig. 4), as the total proportion of individuals attacked per depth range pooled across all trials, or when only missing prey were counted as predation events. Including injured prey that were still attached to tethers as predation events had no effect on the profile of predation presented as the average proportion of individuals taken per depth range per trial (i.e. Fig. 4 has the same profile if injured prey were not counted), but it did slightly change the overall proportion of individuals taken per depth range. Overall there were proportionally more individuals injured but not taken in $<0.5 \mathrm{~m}$ of water. The highest proportion of missing prey, pooled across all experiments, was between 1.5 and $2.5 \mathrm{~m}$ depth.

\section{Survival time and chronograph success}

The chronograph triggering mechanism worked reasonably well. Survival time was successfully measured for 25 of the 46 predation events $(54.4 \%)$. Of the 32 predation events in which the tethered prey was missing, $23(71.9 \%)$ successfully recorded survival time, while only 2 of the 14 events $(14.3 \%)$ in which the prey was still attached to the tether but showed signs of attack successfully triggered the switch mechanism. Failure of the trigger mechanism when the prey was missing was usually due to sand fouling and jamming of the switch slide, while failure of the trigger when the prey remained attached but showed signs of attack was apparently due to insufficient force on the tether line by predators. The switch was triggered 4 times 
$(2.2 \%$ of total sets) when the prey was not taken and showed no signs of attack by predators.

The average $( \pm 1 \mathrm{SE})$ survival time was $55 \pm 8.7 \mathrm{~min}$. Between 1 and 8 successful measurements of survival time were recorded in each of the $0.5 \mathrm{~m}$ depth zones and there was no clear pattern in survival time related to depth (Fig. 5). The shortest recorded survival time of 1 min was recorded in $1.8 \mathrm{~m}$ of water, while the longest (157 $\mathrm{min}$ ) was recorded at $0.35 \mathrm{~m}$ depth.

\section{DISCUSSION}

\section{Depth-related patterns in predation pressure}

Despite the findings of previous studies (e.g. McIvor \& Odum 1988, Ruiz et al. 1993, Manderson et al. 2004), there was no clear evidence that predation pressure on small juvenile fishes was lower in shallow waters than in the adjacent deeper waters in the present study (Table 1, Fig. 3). The profile of predation pressure was highly variable (Fig. 3). In some experimental trials, predation was focused in deeper waters $(>1.5 \mathrm{~m})$, while in others, predation events were recorded exclusively on fish tethered in shallow water. Published tethering studies from other parts of the world have reported clear differences in predation pressure between treatments (Table 2). While not all of the studies listed in Table 2 examined the effect of depth on predation pressure, the sample sizes were large enough in each study to detect a clear pattern between treatments. For example, in just 3 experimental trials, McIvor \& Odum (1988) found a clear and consistent pattern of higher predation pressure on fish tethered in deep waters adjacent to erosional banks than on those

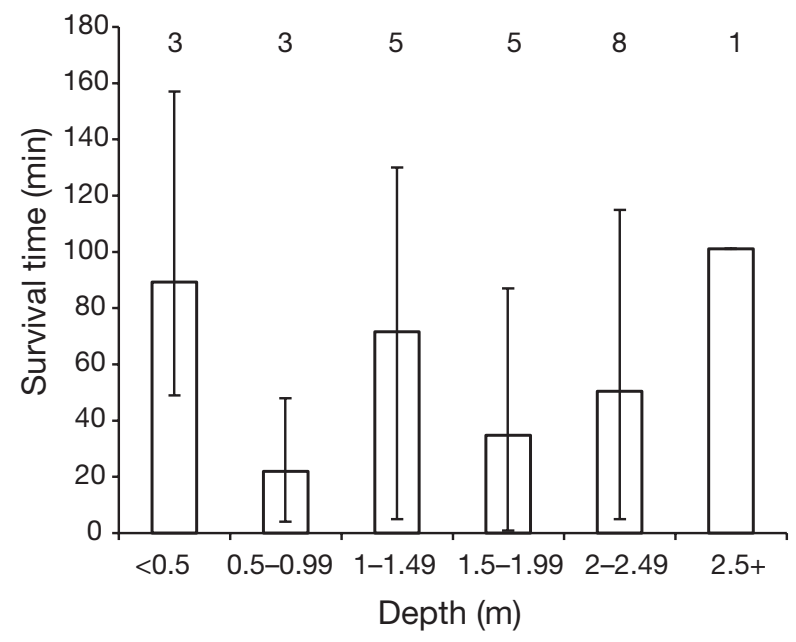

Fig. 5. Average survival time of fish prey tethered across a depth gradient in the lower reaches of a tropical estuary. Bars indicate range. Number of survival time records for each depth zone is shown above each bar tethered in shallower water on depositional banks. The lack of any clear depth-related pattern in predation pressure in the present study was despite the sample size being similar to or greater than that in many previous studies (Table 2).

The studies which have provided the strongest direct support for the shallow-water refuge paradigm were all conducted in temperate systems along the Atlantic coast of North America; 3 of these were within the Chesapeake Bay system (McIvor \& Odum 1988, Ruiz et al. 1993, Clark et al. 2003, Manderson et al. 2004). Estuaries along the mid-Atlantic coast have much less diverse piscivore assemblages than those of the tropical Indo-West Pacific (cf. Hartman \& Brandt 1995, Baker \& Sheaves 2005). It is possible that differences in the piscivore assemblages between these regions may contribute to the conflicting results in the present study.

Based on predator-prey size relationships, $>30$ of the piscivore taxa identified by Baker \& Sheaves (2005) regularly attain sizes large enough (150 to $200 \mathrm{~mm}$ ) to consume prey across the size range tethered during the present study. In the lower reaches of estuaries in northeastern Queensland, the large piscivore assemblage is dominated year-round by members of the families Belonidae, Carangidae, Platycephalidae, Sparidae, and Sphyraenidae (Baker \& Sheaves 2005, 2006, Sheaves 2006), and the fish tethered in the present study are common in the diets of these predators (Baker \& Sheaves 2005). Given the limited knowledge of predation processes in this region, it is difficult to speculate further on the likely combinations of predators responsible for the predation mortality measured during the experiments. For example, although platycephalids have been recorded in high densities in shallow-water habitats in Victoria Creek (Baker \& Sheaves 2006), these are sedentary ambush predators (Douglas \& Lanzing 1981), and as such, even at relatively high densities, encounter rates between platycephalids and tethered prey may be lower than for other more mobile predators such as carangids and belonids. The lack of any clear depth-related patterns in mortality in the present study may be reflective of high local variability in the piscivore assemblage present at any given time. However, the spatial extent of the present study is limited and further research is required to determine whether variable predation pressure is a feature of the region's estuaries.

\section{Experimental validity}

In light of potential confounding factors in tethering experiments, it is important to discuss the validity of the experimental design. Serious interactions between 


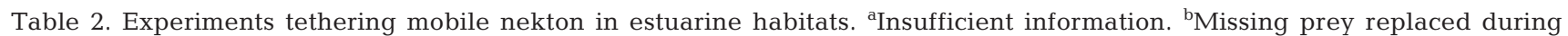
experiment. 'Did not use chronographs. ?estimated

\begin{tabular}{|c|c|c|c|c|c|c|c|c|}
\hline Location & Prey & $\begin{array}{c}\text { Trials } \\
\text { (total sets) }\end{array}$ & $\begin{array}{l}\text { Soak } \\
\text { time } \\
\text { (h) }\end{array}$ & $\begin{array}{l}\text { Mortality } \\
(\%)\end{array}$ & $\begin{array}{c}\text { Avg. } \\
\text { survival } \\
\text { time (min) }\end{array}$ & $\begin{array}{l}\text { Distance } \\
\text { between } \\
\text { tethers (m) }\end{array}$ & $\begin{array}{c}\text { Chronograph } \\
\text { efficiency (\% } \\
\text { successful record) }\end{array}$ & Source \\
\hline Northern Australia & $\begin{array}{c}\text { Fish } \\
\text { (various spp.) }\end{array}$ & $17(183)$ & $2-3$ & 25.1 & 55 & $\geq 20$ & 54.4 & Present study \\
\hline Northern Australia & $\begin{array}{c}\text { Shrimp } \\
\text { (Penaeus sp.) }\end{array}$ & $3(92)$ & 12 & $53.1-92.9$ & $294-583$ & $<3$ & 73.5 & $\begin{array}{l}\text { Haywood \& } \\
\text { Pendrey (1996) }\end{array}$ \\
\hline Rhode Island, USA & $\begin{array}{c}\text { Fish (Fundulus } \\
\text { heteroclitus) }\end{array}$ & $9\left(270^{? a}\right)$ & $120-192$ & $a, b$ & c & a & c & Halpin (2000) \\
\hline \multicolumn{3}{|c|}{$\begin{array}{l}\text { New Jersey, USA } \begin{array}{c}\text { Fish (Pseudo- } \\
\text { pleuronectes americanus) }\end{array} \\
\text { 12(239) }\end{array}$} & 4 & 54 & 96 & 3 & 24 & $\begin{array}{l}\text { Manderson } \\
\text { et al. (2004) }\end{array}$ \\
\hline Virginia, USA & $\begin{array}{c}\text { Fish } \\
\text { (F. heteroclitus) }\end{array}$ & $4(80)$ & $2-3$ & $10-30$ & c & $\geq 2$ & c & $\begin{array}{l}\text { Rozas \& } \\
\text { Odum (1988) }\end{array}$ \\
\hline Chesapeake Bay, USA & A $\underset{(F . \text { heteroclitus })}{\text { Fish }}$ & $1^{\text {?a }}(68)$ & 1.5 & 46 & c & 2 & c & $\begin{array}{l}\text { Ruiz } \\
\text { et al. (1993) }\end{array}$ \\
\hline Chesapeake Bay, USA & A $\underset{\text { (F. heteroclitus) }}{\text { Fish }}$ & $3(90)$ & $2-3$ & 17.8 & c & a & c & $\begin{array}{l}\text { McIvor \& } \\
\text { Odum (1988) }\end{array}$ \\
\hline $\begin{array}{r}\text { Chesapeake Bay, USA } \\
(P\end{array}$ & $\begin{array}{l}\text { A Shrimp } \\
\text { Palaemontes pugic }\end{array}$ & $12\left(216-288^{? a}\right)$ & 2.5 & $<20$ to $>60$ & c & a & c & $\begin{array}{l}\text { Clark } \\
\text { et al. (2003) }\end{array}$ \\
\hline Maine \& Florida, USA & $\begin{array}{l}\text { Shrimp \& } \\
\text { crab }\end{array}$ & $13(222)$ & 12 & $30.2^{\mathrm{b}}$ & $15-315$ & $\geq 3$ & 61.2 & $\begin{array}{l}\text { Peterson } \\
\text { et al. (2001) }\end{array}$ \\
\hline Texas, USA & $\begin{array}{c}\text { Shrimp } \\
\text { (Penaeus aztecus) }\end{array}$ & $1(39)$ & $\geq 19$ & 95 & $266-711$ & Mean $=100$ & $33.3-66.7$ & Minello (1993) \\
\hline
\end{tabular}

tethering artefacts and treatment are most likely to occur in studies comparing habitats that differ considerably in physical structure, where the treatments are widely separated, and/or the assemblages of potential predators are known to differ between treatments (Peterson \& Black 1994). The assessment of potential interactions between tethering artefacts and treatment is very difficult (Peterson \& Black 1994); however, the potential for significant interactions in the present study was minimal. The treatment (depth) was a continuous variable, gradually changing across an experimental site with the deepest and shallowest treatments separated by $<100 \mathrm{~m}$ of gradually sloping, basically featureless sandy bottom. Other than depth, all observable habitat characteristics which may interact with and affect the vulnerability of tethered prey remained constant. It seems unlikely that the effect of the tether on prey behaviour and vulnerability would vary substantially across the depth range sampled.

The simple physical structure of the study sites used in the present study and the location of all depth treatments within a single site minimises the probability of significant differences in the suite of potential predators between treatments. A large proportion of the fishes capable of attacking or removing the prey tethered in this study are naturally piscivorous to some degree (Baker \& Sheaves 2005), making them legitimate potential predators. Potential scavengers such as portunid crabs are relatively abundant in some estuarine habitats in the region (e.g. Haywood et al. 2003); however, these rarely occur in seine net or trap samples from habitats such as those used in the present study (M. Sheaves unpubl. data) and it seems unlikely that crabs would have contributed significantly to the measured predation events. Birds inflict heavy mortality on fishes occupying shallow estuarine habitats in some parts of the world (e.g. Crowder et al. 1997) and prey tethered in shallow waters may become particularly vulnerable to avian predators. However, avian predation appears to be less important in tropical estuaries of northeastern Australia (Blaber 1980) and there were no observations of actively feeding birds during the experimental trials. Thus the potential for any depth-related patterns in predation pressure to be confounded with predation by predators not normally capable of capturing non-tethered prey seems minimal in the present study.

Curran \& Able (1998) found species-specific artefacts during laboratory studies comparing the effects of tethering on prey behaviour and vulnerability for different combinations of predators and prey. They concluded that experiments using tethered fish should be interpreted with caution and that laboratory experiments should be conducted to examine predator and prey species-specific artefacts before field trials are run (Curran \& Able 1998). While caution is clearly required in interpreting tethering studies, the extensive laboratory experiments required to adequately examine species-specific artefacts for different predators from such a diverse piscivore assemblage present 
in the region's estuaries were well beyond the scope of the present study. For example, the aquarium facilities required to house and replicate experiments examining predation by even a few common piscivores, which range from small relatively sedentary predators such as small platycephalids up to large highly mobile predators such as carangids (Baker \& Sheaves 2005), would be immense and were simply not available.

Because of the experimental design, the structure of the study sites, and the efforts to overcome potential confounding problems, the results of the present study should be reliable and interpretable as reflecting natural depth-related patterns in predation pressure.

\section{Implications for refuge paradigm and nursery- ground functioning}

Predation has the potential to be a major structuring force on shallow-water estuarine nursery assemblages, particularly through the consumption of new recruits (Sheaves 2001, Baker \& Sheaves 2005). Prey smaller than those used in the present study could not be successfully tethered due to high mortality during capture, handling, and tethering. Consequently, the prey used during the present study were quite large relative to their size at recruitment (Robertson \& Duke 1990) and relative to the size of many of the piscivores which prey on new recruits (Baker \& Sheaves 2005). Thus the measured predation pressure is unlikely to represent predation pressure on new recruits because the tethered prey were not vulnerable to the same range of predators as new recruits. However, if there is no clear shallow-water refuge for fish of the size tethered, then it seems unlikely that a depth-related refuge can account for the shallow-water distributions of smaller fish (e.g. Fig. 1g). This is because the shallow-water refuge paradigm implies that small fish gain access to water that is shallow enough to reduce the efficiency of or exclude larger fish which prey on them (Ruiz et al. 1993). For example, if $1 \mathrm{~m}$ deep water does not exclude the predators of Sillago spp. 45 to $75 \mathrm{~mm}$ tethered during this study, then it seems unlikely that it would provide refuge for Sillago recruits $<20 \mathrm{~mm}$.

The shallow waters occupied by many small and juvenile fishes in this region (Fig. 1) are too deep to physically exclude the majority of their fish predators (Baker \& Sheaves 2005), and high densities of large piscivores have been recorded in these habitats (Baker \& Sheaves 2006). The findings of the present study do not suggest that predation plays no role in the distribution patterns of fishes within the regions estuaries, but rather that the shallow-water refuge paradigm appears inadequate to explain the observed prey depth distributions.
Sublethal effects of predation, such as the stimulation of energetically expensive defensive strategies, may be a significant mechanism through which predation can influence prey behaviours (Abrams 1993, Preisser et al. 2005). Consequently, there may have to be little difference in the actual consumption of fish prey between shallow and deep habitats to cause the observed distribution patterns of small fishes. If sublethal effects are less costly in shallow than in deep water, then predation may be a significant factor driving the shallow-water distribution, even if actual predation mortality differs little across the depth range (Abrams 1993, Preisser et al. 2005). For example, the cost of vigilance may be less in shallow waters because there are fewer directions from which a predator can approach (Hixon \& Carr 1997). In such circumstances, small fishes in shallow waters could spend less time monitoring for predators and more time foraging.

Because a large proportion of small and juvenile fishes in estuarine systems inhabit shallow-water habitats (Blaber 1980, Kneib 1997, Sheaves 2006), these are the very habitats in which predators would be expected to focus their foraging (Hughes 1980, Craig \& Crowder 2000, Baker \& Sheaves 2005). The potential benefit gained by small fishes inhabiting shallow waters may be that predation is less efficient in these habitats than in the adjacent deeper waters. Consequently, even if the majority of predation pressure on small and juvenile fishes is in shallow-water habitats, predation mortality may be lower than if these fishes were to occupy adjacent deeper waters. In such cases, small and juvenile fishes may still benefit from reduced predation mortality in shallow habitats with high predation pressure.

The scenarios above present challenges to determining the mechanisms by which predation may drive habitat use by small and juvenile fishes. This is because although it may be possible to measure relative predation pressure between habitats, it is very difficult to quantify what predation mortality would be if small and juvenile fishes exhibited different distribution patterns. Regardless of the challenges, the effective management of estuarine nurseries requires a clear understanding of the processes driving habitat use in order to identify and protect important habitats (Craig \& Crowder 2000, Sheaves et al. 2006).

Acknowledgements. We thank R. Johnston for his contribution of data on the depth distributions of common small fishes from the region. Thanks also to the many field volunteers, particularly K. Abrantes, T. Cornish, J. Baker, and T. Squires. R. Rountree and an anonymous reviewer provided comments on the thesis chapter on which this paper is based, and their comments greatly improved this paper. We also thank 3 anonymous reviewers who provided helpful suggestions and criticisms. This research was funded by the Coastal CRC and the Department of Marine Biology and Aquaculture, James Cook University. 


\section{LITERATURE CITED}

Abrams PA (1993) Why predation rate should not be proportional to predator density. Ecology 74:726-733

Aronson RB, Heck KL (1995) Tethering experiments and hypothesis testing in ecology. Mar Ecol Prog Ser 121: 307-309

Aronson RB, Heck KL, Valentine JF (2001) Measuring predation with tethering experiments. Mar Ecol Prog Ser 214: 311-312

Baker R, Sheaves M (2005) Redefining the piscivore assemblage of shallow estuarine nursery habitats. Mar Ecol Prog Ser 291:197-213

Baker R, Sheaves M (2006) Visual surveys reveal high densities of large piscivores in shallow estuarine nurseries. Mar Ecol Prog Ser 323:75-82

Barshaw DE, Able KW (1990) Tethering as a technique for assessing predation rates in different habitats: an evaluation using juvenile lobsters Homarus americanus. Fish Bull 88:415-417

Blaber SJM (1980) Fish of the Trinity Inlet system of north Queensland with notes on the ecology of fish faunas of tropical Indo-Pacific estuaries. Aust J Mar Freshw Res 31: 137-146

Blaber SJM, Blaber TG (1980) Factors affecting the distribution of juvenile estuarine and inshore fish. J Fish Biol 17: 143-162

Boesch D, Turner RE (1984) Dependence of fishery species on salt marshes: the role of food and refuge. Estuaries 7: $460-468$

Clark KL, Ruiz GM, Hines AH (2003) Diel variation in predator abundance, predation risk and prey distribution in shallowwater estuarine habitats. J Exp Mar Biol Ecol 287:37-55

Craig JK, Crowder LB (2000) Factors influencing habitat selection in fishes with a review of marsh ecosystems. In: Weinstein MP, Kreeger DA (eds) Concepts and controversies in tidal marsh ecology. Kluwer, Dordrecht, p 241-266

Crowder LB, Squires DD, Rice JA (1997) Nonadditive effects of terrestrial and aquatic predators on juvenile estuarine fish. Ecology 78:1796-1804

Curran MC, Able KW (1998) The value of tethering fishes (winter flounder and tautog) as a tool for assessing predation rates. Mar Ecol Prog Ser 163:45-51

Deegan LA, Hughes JE, Rountree RA (2000) Salt marsh ecosystem support of marine transient species. In: Weinstein MP, Kreeger DA (eds) Concepts and controversies in tidal marsh ecology. Kluwer, Dordrecht, p 333-365

Douglas WA, Lanzing WJR (1981) The respiratory mechanisms of the dusky flathead, Platycephalus fuscus (Platycephalidae, Scorpaeniformes). J Fish Biol 18:545-552

Halpin PM (2000) Habitat use by an intertidal salt-marsh fish: trade-offs between predation and growth. Mar Ecol Prog Ser 198:203-214

Hartman KJ, Brandt SB (1995) Predatory demand and impact of striped bass, bluefish, and weakfish in the Chesapeake Bay: applications of bioenergetics models. Can J Fish Aquat Sci 52:1667-1687

Haywood MDE, Pendrey RC (1996) A new design for a submersible chronographic tethering device to record predation in different habitats. Mar Ecol Prog Ser 143:307-312

Haywood MDE, Manson FJ, Loneragan NR, Toscas PJ (2003) Investigation of artifacts from chronographic tethering experiments - interactions between tethers and predators. J Exp Mar Biol Ecol 290:271-292

Hixon MA, Carr MH (1997) Synergistic predation, density dependence, and population regulation in marine fish. Science 277:946-949

Editorial responsibility: Kenneth Heck (Contributing Editor), Dauphin Island, Alabama, USA
Hughes RN (1980) Optimal foraging theory in the marine context. Oceanogr Mar Biol Annu Rev 18:423-481

Kneib RT (1997) The role of tidal marshes in the ecology of estuarine nekton. Oceanogr Mar Biol Annu Rev 35:163-220

Kneib RT, Scheele CH (2000) Does tethering of mobile prey measure relative predation potential? An empirical test using mummichogs and grass shrimp. Mar Ecol Prog Ser 198:181-190

Manderson JP, Pessutti J, Hilbert JG, Juanes F (2004) Shallow water predation risk for a juvenile flatfish (winter flounder, Pseudopleuronectes americanus Walbaum) in a northwest Atlantic estuary. J Exp Mar Biol Ecol 304: $137-157$

McIvor CC, Odum WE (1988) Food, predation risk, and microhabitat selection in a marsh fish assemblage. Ecology 69: $1341-1351$

Minello TJ (1993) Chronographic tethering: a technique for measuring prey survival time and testing predation pressure in aquatic habitats. Mar Ecol Prog Ser 101:99-104

Minello TJ, Able KW, Weinstein WP, Hays CG (2003) Salt marshes as nurseries for nekton: testing hypotheses on density, growth and survival through meta-analysis. Mar Ecol Prog Ser 246:39-59

Paterson AW, Whitfield AK (2000) Do shallow-water habitats function as refugia for juvenile fishes? Estuar Coast Shelf Sci 51:359-364

Peterson BJ, Thompson KR, Cowan JH, Heck KL (2001) Comparison of predation pressure in temperate and subtropical seagrass habitats based on chronographic tethering. Mar Ecol Prog Ser 224:77-85

Peterson CH, Black R (1994) An experimentalist's challenge: when artifacts of intervention interact with treatments. Mar Ecol Prog Ser 111:289-297

Preisser EL, Bolnick DI, Benard MF (2005) Scared to death? The effects of intimidation and consumption in predatorprey interactions. Ecology 86:501-509

Robertson AI, Duke NC (1990) Recruitment, growth and residence time of fishes in a tropical Australian mangrove system. Estuar Coast Shelf Sci 31:723-743

Rountree RA, Able KW (1997) Nocturnal fish use of a New Jersey marsh creek and adjacent bay shoal habitats. Estuar Coast Shelf Sci 44:703-711

Rountree RA, Able KW (2006) Spatial and temporal habitat use patterns for salt marsh nekton: implications for ecological functions. Aquat Ecol 41:25-45

Rozas LP, Minello TJ (1997) Estimating densities of small fishes and decapod crustaceans in shallow estuarine habitats: a review of sampling design with focus on gear selection. Estuaries 20:199-213

Rozas LP, Odum WE (1988) Occupation of submerged aquatic vegetation by fishes: testing the roles of food and refuge. Oecologia 77:101-106

Ruiz GM, Hines AH, Posey MH (1993) Shallow water as a refuge habitat for fish and crustaceans in non-vegetated estuaries: an example from Chesapeake Bay. Mar Ecol Prog Ser 99:1-16

Sheaves M (2001) Are there really few piscivorous fishes in shallow estuarine habitats? Mar Ecol Prog Ser 222:279-290

Sheaves M (2005) Nature and consequences of biological connectivity in mangrove systems. Mar Ecol Prog Ser 302: 293-305

Sheaves M (2006) Scale-dependent variation in composition of fish fauna among sandy tropical estuarine embayments. Mar Ecol Prog Ser 310:173-184

Sheaves M, Baker R, Johnston R (2006) Marine nurseries and effective juvenile habitats: an alternative view. Mar Ecol Prog Ser 318:303-306

Submitted: September 1, 2006; Accepted: June 1, 2007

Proofs received from author(s): October 22, 2007 